\title{
DOES THE FINANCIAL SYSTEM PROMOTE SUSTAINABLE DEVELOPMENT? EVIDENCE FROM EASTERN EUROPEAN COUNTRIES
}

\author{
Moldovan (Gavril), I. A.
}

\begin{abstract}
This article aims at analyzing the relationship between sustainable development and the financial system, mainly focusing on the role that the financial system plays within the process of sustainable development. Theoretically, the financial system could be a very important factor to promote sustainable development, as it could foster economic growth and development, efficient resource allocation, the protection of the environment and also social responsibility. Using panel data econometrical analysis, we tested for correlations between indicators of the financial system and indicators of sustainable development in five developing Eastern European countries. We found weak or no correlation between financial indicators and sustainable development indicators. This might be explained by several facts. First, the financial systems of these five developing countries are not highly developed, so that they do not have a high capacity to foster economic growth and development. Second, even if this was the case, promoting sustainable development requires a lot more than fostering economic growth and is not a question of whether the financial companies can promote sustainability, but whether they are interested in promoting it. Even though financial companies have embraced the sustainability agenda, they haven't done much to change their short-term orientation to profit and to shift to long-run strategies in favor of sustainable development. ${ }^{1}$
\end{abstract}

Keywords: financial system; sustainable development; Eastern Europe; panel data analysis JEL classification: G10, I00, O1

\section{Introduction}

Recent economic developments have shown that the financial system is probably the most important tool to promote sustainable economic development, as the recent financial turmoil has shown what happens when it does not work properly. Although financial companies and institutions have increasingly embraced the sustainability agenda over the past decade, the best part of the funds they allocate are still directed to resource-inefficient and polluting economic activities. At the same time, social and economic inequalities are widening, to the detriment of developing countries compared to developed ones. Allocating funds for sustainable economic development of developing countries remains a great challenge for the financial system.

When talking about sustainable development, a wide range of aspects are embodied (Davidescu and Strat, 2014). Theoretically, the financial system could be a very important factor to promote sustainable development, as it could foster economic growth and development, efficient resource allocation, the protection of the environment and also

1 An earlier version of this paper has been presented at the 15th International Joint Conference: Central and Eastern Europe in the Changing Business Environment, in Prague, May 29, 2015. 
social responsibility. First, the financial system can foster economic growth by the fact that it collects and mobilizes savings, allocates funds for investment and provides capital accumulation. The financial system's capacity to ensure a continuous way of financing the real economy is a very important factor for economic development. Second, it could determine efficient resource allocation and it could contribute to the protection of the environment by screening and funding viable and environmentally friendly projects only. Moreover, financial companies are able to promote social responsible activities, by including such activities in their strategies and by selecting and dealing only to social responsible economic agents, or even by providing methods for managing uncertainty and controlling risk through portfolio diversification (Moldovan, 2015a).

This paper presents an econometrical analysis on the relationship between the financial system and the process of sustainable development in five Eastern European countries: Romania, Poland, Hungary, Bulgaria and Czech Republic. The main goal of the paper is to test the importance of the financial system for sustainable development in the above mentioned countries, and more precisely to show if the financing provided by the financial system encourages the process of sustainable economic development.

The paper is organized as follows: the first section describes a series of theoretical and empirical findings about the relationship between the financial system and sustainable development, the second section presents the econometric analysis and its results, and the final section concludes, suggests policy recommendations and outlines the directions of future research.

\section{Literature Review}

As mentioned above, the financial system may be a great factor to promote sustainability and sustainable development, but the reality shows that this is not quite the case. Due to the fact that financial companies control and redirect great amounts of money, they could act in favor of sustainable development of the economy and society. However, several papers show that the nature of the financial system is not compatible with the activities and determinants of sustainable development (Schmidheiny and Zorraquin, 1996; Pisano et al., 2012). This is mainly because the main concern of the financial system is achieving immediate and consistent gains, while sustainable development requires long run investments. Short-termism has detrimental effects on financial markets, the real economy and society (Lydenberg, 2007).

Also, one of the greatest issues when speaking of sustainable development regards the disparities between developed countries and the developing or Third World countries. Worldwide policies of sustainable development should provide aid and financing for these countries, but there arises the reluctance of financial companies for investing or funding projects in such states, because they are considered to be very risky.

The importance of the financial system for promoting economic growth has been subject of a great number of papers. Numerous econometric analyses have captured a positive relationship between financial development and economic growth (King and Levine, 1993a; Becivenga and Smith, 1991; Peetz and Genreith, 2011).

However, sustainable development requires more than the quantitative expansion of economic activities. Thus, a number of works have put into light the relationship between financial development and environmental quality, showing that financial development is 
an important determinant of environmental quality. This is because developed financial systems have the capacity to finance environmental projects at low costs (Claessens and Feijen, 2007; Tamazian et al., 2009; Halicioglu, 2009; Tamazian and Rao, 2010).

Moreover, financial intermediaries ensure allocation of resources to the most advanced technologies (Jalil and Feridun, 2010), and may even contribute to fostering technological innovation (King and Levine, 1993b; Tadesse, 2005).

On the other hand, there are studies that refute the existence of a positive impact of financial development on the environment. For example, Mohamed Amine Boutabba explores the relationship between financial development and carbon emissions in India, concluding that financial development emphasizes environmental pollution (Boutabba, 2014).

At the same time, capital markets can play an important role in promoting environmental protection, as the market value of companies that do not meet national environmental standards tends to decrease because of this neglect (Tamazian et al., 2009).

Other studies refer to the link between economic growth and the level of pollution, most of them revealing that this is a „U-shaped relationship” (also known as the Kuznets curve), as initial growth contributes to environmental degradation, but after reaching a certain level of growth, it leads to reduction of pollution (Grossman and Krueger, 1995; Selden and Song, 1994).

\section{Econometric analysis}

We have tested the influence of the financial system on sustainable development in five Central and Eastern European countries (Romania, Poland, Hungary, Bulgaria and Czech Republic) by using multiple regressions based on panel data over the period 2000-2013.

\subsection{Data}

We opt for the Anglo-Saxon approach of the financial system's structure, according to which this is composed of the monetary market (whose main role is to provide liquidity through credit) and the capital market (whose main role is to finance investments through initial public offers). The Anglo - Saxon approach was most often used in recent years, to the detriment of the continental approach according to which the capital market is composed of the financial market and money market. However, the differentiation between the two approaches is not about essence, but rather about name.

Therefore, we use domestic credit provided by the financial sector as a share of GDP (CREDIT) and stock market capitalization as a share of GDP (MCAP) in order to capture the effects of the financial system on sustainable development indicators. We have collected the data for the financial indicators from the World Bank (2015).

We also use the headline sustainable development indicators provided by the European Commission in order to monitor the EU Sustainable Development Strategy. The European Commission has developed a set of indicators for sustainable development classified into themes, each theme having one or several headline indicators. These headline indicators have been identified of more than 100 indicators and are expected to assess the progress of EU member states towards sustainable development, according to the objectives defined by the EU Sustainable Development Strategy. They are presented in the Table 1. 
Table 1 | Sustainable Development Headline Indicators

\begin{tabular}{|l|l|}
\hline Theme & Headline indicator \\
\hline Socio-economic development & Growth rate of real GDP per capita \\
\hline Sustainable consumption and production & Resource productivity \\
\hline Social inclusion & Persons at-risk-of-poverty or social exclusion \\
\hline Demographic changes & Employment rate of older workers \\
\hline Public health & Healthy life years and life expectancy at birth, by sex \\
\hline Climate change and energy & $\begin{array}{l}\text { Greenhouse gas emissions } \\
\text { Share of renewable energy in gross final energy } \\
\text { consumption } \\
\text { Primary energy consumption }\end{array}$ \\
\hline Sustainable transport & Energy consumption of transport relative to GDP \\
\hline Natural resources & Common bird index \\
\hline Global partnership & $\begin{array}{l}\text { Official development assistance as share of gross } \\
\text { national income }\end{array}$ \\
\hline Good governance & No headline indicator \\
\hline
\end{tabular}

Source: Eurostat (2015).

We use almost all of these headline indicators in our analysis, respectively: growth rate of real GDP per capita (RGDP), resource productivity (RESOURCE PRODUCTIVITY), people at risk of poverty as a share of total population (POVERTY), employment rate of older workers as a share of total employment (OLD_EMPLOYMENT), healthy life years expectancy at birth (HEALTH), greenhouse gas emissions (GAS), share of renewable energy in gross final energy consumption (RENEW_EN), primary energy consumption (ENERGY), energy consumption of transport relative to GDP (TRANSPORT) and official development assistance as share of gross national income (ODA).

\subsection{Methodology and Results}

We use panel data and multiple regression models in order to estimate the influence of the financial system upon sustainable development indicators.

Each of the sustainable development indicators $\left(S D_{\text {indicator }}\right)$ has been considered as an endogenous variable in multiple regressions within which the financial indicators have been exogenous variables. Thus, each regression had the following form:

$$
S D_{\text {indicator }}=c+a \cdot \text { credit }+b \cdot \text { mcap }+\varepsilon,
$$

where $c$ is the constant term of the equation; $a$ and $b$ are the coefficients associated with each exogenous variable; $\varepsilon$ is the error term. The main results of the regression models are presented in Table 2. 
Table 2 | Results of regression equations

\begin{tabular}{|c|c|c|c|c|c|c|c|}
\hline $\begin{array}{l}\text { Dependent } \\
\text { variable }\end{array}$ & $\begin{array}{c}\text { Inde- } \\
\text { pendent } \\
\text { variables }\end{array}$ & Coefficient & T-statistic & $\begin{array}{l}\text { Prob. } \\
\text { (T-sta- } \\
\text { tistic) }\end{array}$ & $\mathbf{R}^{2}$ & $\begin{array}{l}\text { F-sta- } \\
\text { tistic }\end{array}$ & $\begin{array}{l}\text { Prob. } \\
\text { (F-sta- } \\
\text { tistic) }\end{array}$ \\
\hline \multirow{2}{*}{ RGDP } & CREDIT & $2.3806^{* *}$ & 2.5211 & 0.0141 & \multirow{2}{*}{0.2331} & \multirow{2}{*}{9.4265} & \multirow{2}{*}{0.0002} \\
\hline & MCAP & $3.7700 * * *$ & 3.6498 & 0.0005 & & & \\
\hline \multirow{2}{*}{$\begin{array}{l}\text { RESOURCE } \\
\text { PRODUCTIVITY }\end{array}$} & CREDIT & -0.9300 & -1.3512 & 0.1796 & \multirow{2}{*}{0.1091} & \multirow{2}{*}{3.7992} & \multirow{2}{*}{0.0272} \\
\hline & MCAP & $1.6278^{* *}$ & 2.1487 & 0.0361 & & & \\
\hline \multirow{2}{*}{ POVERTY } & CREDIT & $1.2045^{*}$ & 2.0076 & 0.0527 & \multirow{2}{*}{0.1077} & \multirow{2}{*}{2.0524} & \multirow{2}{*}{0.0446} \\
\hline & MCAP & $-1.3092^{*}$ & -1.9992 & 0.0536 & & & \\
\hline \multirow{2}{*}{$\begin{array}{l}\text { OLD_} \\
\text { EMPLOYMENT }\end{array}$} & CREDIT & $-0.4352^{*}$ & -1.9315 & 0.0580 & \multirow{2}{*}{0.0569} & \multirow{2}{*}{1.8720} & \multirow{2}{*}{0.0623} \\
\hline & MCAP & $0.4340^{*}$ & 1.7545 & 0.0843 & & & \\
\hline \multirow{2}{*}{ HEALTH } & CREDIT & -0.0346 & -0.1752 & 0.8619 & \multirow{2}{*}{0.0335} & \multirow{2}{*}{0.5906} & \multirow{2}{*}{0.0595} \\
\hline & MCAP & 0.1038 & 0.4815 & 0.6332 & & & \\
\hline \multirow{2}{*}{ ENERGY } & CREDIT & 0.2727 & 1.5298 & 0.1336 & \multirow{2}{*}{0.2917} & \multirow{2}{*}{8.6513} & \multirow{2}{*}{0.0007} \\
\hline & MCAP & $-0.5387^{* *}$ & -2.7559 & 0.0086 & & & \\
\hline \multirow{2}{*}{ RENEW_EN } & CREDIT & $0.3321^{* *}$ & 2.3750 & 0.0207 & \multirow{2}{*}{0.1891} & \multirow{2}{*}{7.2317} & \multirow{2}{*}{0.0015} \\
\hline & MCAP & $-0.5065^{* * *}$ & -3.2990 & 0.0016 & & & \\
\hline \multirow{2}{*}{ GAS } & CREDIT & -0.3802 & -1.2456 & 0.2176 & \multirow{2}{*}{0.3338} & \multirow{2}{*}{15.5374} & \multirow{2}{*}{0.0000} \\
\hline & MCAP & $1.0563^{* * *}$ & 3.1519 & 0.0025 & & & \\
\hline \multirow{2}{*}{ TRANSPORT } & CREDIT & -0.2065 & -1.0189 & 0.3122 & \multirow{2}{*}{0.1638} & \multirow{2}{*}{6.0740} & \\
\hline & MCAP & $0.4831^{* *}$ & 2.1706 & 0.0338 & & & 0.0039 \\
\hline & CREDIT & $0.0004^{* *}$ & 3.1139 & 0.0028 & & & \\
\hline I & MCAP & 0.0004 & 1.5051 & 0.1374 & 0.2100 & 8.2410 & 0.0000 \\
\hline
\end{tabular}

Note: * significant at $10 \%$ level, ** - significant at $5 \%$ level, *** -significant at $1 \%$ level Source: Author's calculations based on World Bank (2015) and Eurostat (2015) data.

For each equation, the coefficient of determination $\mathrm{R}^{2}$ is quite low, which means that the change of the dependent variable may be explained by the movements of the independent variables at a low or very low rate.

Considering the significance threshold of $10 \%$, we assume that each equation is correctly specified.

As may be noticed in Table 2, the real GDP per capita (RGDP) is influenced both by credit and by market capitalization, as the coefficients of the independent variables are statistically significant at $1 \%$ or $5 \%$ level, but, as stated above, the coefficient of determination $\mathrm{R}^{2}$ is quite low, 0.23 . 
At the same time, resource productivity is only influenced by market capitalization, as the credit coefficient is not statistically significant, while poverty is positively influenced by credit and negatively influenced by market capitalization, considering the significance threshold of $10 \%$. However, the coefficient of determination $\mathrm{R}^{2}$ is very low, only 0,1 .

The results show that there is a negative correlation between employment rate of older workers as a share of total employment and credit, and a positive correlation between and market capitalization, considering the significance level of $10 \%$. However, the coefficient of determination $\mathrm{R}^{2}$ is very low, 0.05 . At the same time, none of the exogenous variables influences healthy life years expected at birth, as the coefficients of the independent variables are not statistically significant.

Greenhouse gas emissions and primary energy consumption are only influenced by market capitalization, while credit does not influence these two variables, as the coefficients are not statistically significant. This suggests that the size of the capital market influences industrial activity. For these two regression equations, the correlation coefficients are higher, around 0.3 .

The share of renewable energy in gross final energy consumption is positively influenced by credit and negatively influenced by market capitalization, but the coefficient of determination is also low, of 0.18 . This means that sources of renewable energy might be financed through credit, though the influence is very weak.

Energy consumption of transport relative to GDP is not influenced by credit, as the coefficient is not significant, but it is influenced by market capitalization, at a $5 \%$ significance level, but at a low rate (the coefficient of determination $\mathrm{R}^{2}$ is only 0.16 ).

Official development assistance as share of gross national income seems to be positively influenced by credit only, at a $5 \%$ significance level, but the coefficient is very low, only 0.000487 , and moreover, the coefficient of determination $\mathrm{R}^{2}$ is also low, of 0.21 . Market capitalization does not influence official development assistance, as the coefficient is statistically insignificant.

On the whole, we can state that sustainable development indicators are weakly influenced by the financial indicators in the five CEE countries included in the analysis.

\section{Conclusions}

Several authors express a tension between the financial system and sustainable development, as the main concern of the financial system is achieving short-term consistent gains, while sustainable development focuses on long termism. Theoretically speaking, financial companies could be a great factor to promote sustainability and sustainable development, but the reality shows that this is not quite the case.

We test the influence of financial indicators upon some sustainable development indicators in five developing CEE countries (Romania, Poland, Hungary, Bulgaria and Czech Republic) by using multiple regressions based on panel data over the period 2000 - 2013. We find very weak or even no influence from the financial indicators over the sustainable development indicators, as the coefficient of determination varies between 0.05 and 0.33 for the regression equations.

These findings might be explained by several facts. First, the financial systems of these five developing countries are not very well developed, so that they do not have a high capacity to foster economic growth and development. Second, even if this was the 
case, promoting sustainable development requires a lot more than fostering economic growth. It also involves efficient resource allocation, the protection of the environment and social responsibility. It is not a question of whether the financial companies can promote all these, but whether they are interested in promoting them. Unfortunately, the main goal of every financial company is to obtain consistent short-term gains, which is in disagreement with the principles and activities that may contribute to sustainable development. As stated before, even though financial companies have embraced the sustainability agenda, they haven 't done much to change their short-term orientation to profit and to shift to long-run strategies in favor of sustainable development.

One of the problems regarding the financing for sustainable development is about the lack of awareness of its importance, and governments should try to implement informational programs in order to make it popular.

Another problem is about the fact that sustainable development requires green investments, which are more expensive than traditional investments, so that the investors and financiers are reluctant. Therefore, governments should provide incentives to encourage investments directed towards sustainability. For example, governments could promote green investments through tax measures, such as eliminating subsidies to polluting economic activities and/or extra charging them, or eliminating customs duties on goods and services for green investments. Moreover, governments could stimulate green investments by co-financing them, through public-private partnerships, and should also finance research and development activities in order to foster technological innovation, which could make green investment cheaper and more accessible (Moldovan, 2015b).

Estimating sustainable development is a great challenge and future research should focus on estimating a composite index of sustainable development and then testing the correlations between this index and some variables of the financial system. It would be interesting to make such an analysis both for developing and developed countries, in order to observe the differences between the role of the financial system for promoting sustainable development both in developing and developed countries.

\section{References}

Bencivenga, V. R., \& Smith, B. D. (1991). Financial intermediation and endogenous growth. The Review of Economic Studies, 58(2), 195-209.

Boutabba, M. A. (2014). The impact of financial development, income, energy and trade on carbon emissions: Evidence from the Indian economy. Economic Modelling, 40, 33-41.

Claessens, S., \& Feijen, E. (2007). Financial sector development and the millennium development goals (No. 89). World Bank Publications.

Davidescu, A., \& Strat, V. A. (2014). Coordinates of a New Romanian Regional PolicyIdentifying the Development Poles. A Case Study. Informatica Economica, 18(2), 88-99.

Eurostat (2015). Indicators. Retrieved May 24, 2015 from http://ec.europa.eu/eurostat/web/ sdi/indicators.

Grossman, G., \& Krueger, A. (1995). Economic environment and the economic growth, Quarterly Journal of Economics, 110(2), 353-377.

Halicioglu, F. (2009). An econometric study of CO2 emissions, energy consumption, income and foreign trade in Turkey. Energy Policy, 37(3), 1156-1164.

Jalil, A., \& Feridun, M. (2011). The impact of growth, energy and financial development on the environment in China: A cointegration analysis. Energy Economics, 33(2), 284-291. 
King, R. G., \& Levine, R. (1993a); Finance, Entrepreneurship, and Growth: Theory and Evidence, Journal of Monetary Economics, 32(3), 513-542.

King, R. G., \& Levine, R. (1993b). Financial Intermediation and Economic Development, in Capital Markets and Financial Intermediation, ed. Mayer, C., Vives, X., London: Centre for Economic Policy Research.

Lydenberg, S. (2007). Long-term Investing: a proposal for how to define and implement longterm investing. Corporation, 20, 20.

Moldovan (Gavril), I. A. (2015a). Sustainable development and CSR in the financial sector. Annals of the "Constantin Brâncuşi" University of Târgu Jiu, Economy Series, 2015(1), 217-221.

Moldovan (Gavril), I. A. (2015b). Incentives for financing sustainable development. Annals of the "Constantin Brâncuşi" University of Târgu Jiu, Economy Series, 2015(2).

Pisano, U., Martinuzzi, A., \& Bruckner, B. (2012). The financial sector and sustainable development: logics, principles and actors. Quarterly Report, 27)

Peetz, D., \& Genreith, H. (2011). The financial sector and the real economy. Real-world economics review, 57, 41-47.

Schmidheiny, S., \& Zorraquin, F. J. (1996). Financing Change. The Financial Community, Eco-efficiency, and Sustainable Development. Cambridge, MA: The MIT Press.

Selden, T. M., \& Song, D. (1994). Environmental quality and development: is there a Kuznets curve for air pollution emissions? Journal of Environmental Economics and Management, 27(2), 147-162.

Tadesse, S. (2005). Financial Development and Technology. University of Michigan: William Davidson Institute Working Paper 749.

Tamazian, A., \& Rao, B. B. (2010). Do economic, financial and institutional developments matter for environmental degradation? Evidence from transitional economies. Energy Economics, 32(1), 137-145.

Tamazian, A., Chousa, J. P., \& Vadlamannati, K. C. (2009). Does higher economic and financial development lead to environmental degradation: evidence from BRIC countries' Energy policy, 37(1), 246-253.

World Bank (2015). Indicators. Retrieved May 24, 2015 from http://data.worldbank.org/ indicator.

\author{
Author \\ Moldovan (Gavril) loana Andrada, Ph.D \\ Lecturer \\ Department of Economics and Economic Policies \\ The Bucharest University of Economic Studies \\ Piața Romană no. 6, Bucharest, Romania \\ ioanaa.gavril@gmail.com
}

This work was co-financed from the European Social Fund through Sectoral Operational Programme Human Resources Development 2007-2013, project number POSDRU/159/1.5/S/142115 „Performance and excellence in doctoral and postdoctoral research in Romanian economics science domain". 